\title{
Cak Nun, Maiyah, and Fandom: Participatory Culture Perspective
}

\author{
Rony K. Pratama
}

Gadjah Mada University, Indonesia

\section{ARTICLE INFO}

\section{Keywords:}

Cak Nun

Maiyah

Fandom

CyberMovement

Participation

\begin{abstract}
The emergence of Maiyah in the midst of the downstream community marked a new format for recitation focusing on horizontal dialectics based on contextual themes. It can be said that Maiyah is a recitation forum that discusses actual themes such as culture, education, social, economy, religion, etc. by basing universal values such as egalitarian, democratic, and mutual respect. Maiyah has been held for about two decades and carried out in dozens of cities in Indonesia (Yogyakarta, Jakarta, Surabaya, Bandung, Semarang and others) and abroad (Hong Kong, Berlin, Philadelphia, Bangkok, Seoul, Amsterdam, Helsinki, London, and others). The communities which consist of a variety of backgrounds, both economic, class, age, and religion, have a strategic role in the discourse formation on what and how Maiyah is formulated. Such a tendency explains their position, if revealed from the fandom's perspective, it strengthens the relationship between Cak Nun and Maiyah. Cak Nun is widely known as a multidimensional human being: writer, intellectual, islamic scholar, and social activist. Cak Nun and Maiyah, therefore, are reciprocal correlates when viewed from the perspective of fandom. The fandom framework that emerged in the past decade and a half extends to the cyberspace. The emergence of new internet-based media requires the fandom movement in cyberspace. This article uses a fandom theory-Henry Jenkins - and particularly cultural participation perspective. Thus it could be answering the question of how stretching fandom is in the practice of Maiyah and how it appears to be related to the character of Cak Nun.
\end{abstract}

\section{Introduction}

Every month, regularly on the 17th, hundreds to thousands of people gather at Tamantirto, Kasihan, Bantul, Yogyakarta, Indonesia. They consist of crossing social, religious, economic, educational, and age backgrounds but have a similar goal, which is to follow the Mocopat Syafaat. That is a part of Maiyah - the Islamic social movement - that is often interconnected with the main figure of Muhammad Ainun Nadjib (Cak Nun). Many people know him as a multidimensional person: humanist, poet, and columnist (Sumasno, 2011: 54). Apart from the common embodiment that came from the mainstream media, Cak Nun is a person who spends his entire life on social activities (Hefner, 1993). Especially the undercurrent activities in the community of settlements. As a muslim intellectuals, Cak Nun has pivotal thinking in order to beyond "the mainstream path of the renewed Islamic thought" (Yunus \& Luthfi, 2019), either in Indonesia or overseas.

Mocopat Syafaat is only one of the branches of the Maiyah in Indonesia. Each major city, especially in Java, has its own branches such as Kenduri Cinta (Jakarta), Bangbang Wetan

*Corresponding author E-mail address: ronykamtis@gmail.com 
(Surabaya), Padangmbulan (Jombang), and so on. Each affiliate has been established for two decades. However, among these, Padangmbulan in Jombang is the longest branch due to it was founded in the early 90s marked by internal study of the scope of the Cak Nun's family (Rozi, 2005: 64). In addition to Maiyah's activities that are found domestically, Maiyah's resonance also extends to foreign countries, particularly initiated by Indonesian workers such as in Hong Kong, South Korea, Australia, and the United States.

The next question, is Maiyah with such social and cultural capital seems as formal organization like Muhammadiyah and Nahdlatul Ulama? (Peacock, 1978). Answering this question can begin with two simple arguments by reviewing the Maiyah ontology which is conveyed as follows. Firstly, Maiyah is not an organization in the formal sense but has an organized direction - even if culturally — by using Cak Nun as a central figure. Secondly, Maiyah's form tends to scientific forum which is discussed multidisciplinary themes. Even though based on Islamic values, Maiyah do not merely focus on theology but often also include education, economics, social, culture, and so forth.

It is clear that the bacground of Maiyah's movement here after explaining some organizational preferences mention-aboved. What is interesting me to exploring further is how the connection between Maiyah as a multidisciplinary study could attract such a huge mass, although most of them are youngsters (university students). I am a part of it and been there about nine years. Gathering militant members do not make Maiyah converts to formal organization such as political parties. Maiyah is still inclusive forum, independent social movement community. The holding of the position as an informal study there emphasized negotiation between Cak Nun and the Maiyah congregation.

Since Maiyah was founded, there has been no permanent membership, like other formal organizations. This position was stated explicitly by Cak Nun so that Maiyah did not wish and pretended to be an exclusive and formal organization. Moreover, people who follow Maiyah often say as a congregation, either directly or by YouTube. The congregation by YouTube, in other words, can be said to be the most militant because they feel linked by the figure of Cak Nun, both as a teacher who tends to lead and an imaginary figure to dialogue. That position is compounded by their reciprocal relations with congregations across cities or countries.

Their fondness for Cak Nun's charisma made them interested in following Maiyah for hours. I argue that Maiyah stated its forum based on learning together, therefore the questions and answers come from members. In addition to the verbal side which is the main medium for referring to the congregation, there are at least two opinions as to why people feel at home.

First, the carrying of Cak Nun during reviewing, dissecting, and analyzing particular themes necessarily uses a literary-based approach so that the utterances expressed make the listeners feel at home. This is due to Cak Nun had a long standing in dramatic performances. Second, in spite of the discussions in Maiyah, Cak Nun involves KiaiKanjeng (music group) - a genre of music that collaborates traditional music gamelan and modern music - thus builds an artistic-musical nuance that can be understood and enjoyed by audiences.

The totality of the Maiyah congregation who followed the figure of Cak Nun in turn built a public participation. It senses that the relationship between Cak Nun and Maiyah is dialectical on the one hand and liberating on the other hand. I attempted a sort of arguments there. First, this reciprocal participation includes how their interaction is not just a teacher and student relationship, but goes beyond personal barriers by considering Cak Nun as a father or grandfather.

It such closeness that seems to be considered fluid and dynamic in the Maiyah, even though the naming of fathers or grandfathers there tends to be cultural-rooted. Second, the first point about dialectical participation is then strengthened by the liberation of the Maiyah congregation to further develop or implement any knowledge gained during the process as an 
emancipatory effort at any level, whether that is in the field of personal, family, or the surrounding community.

Those are major points why Maiyah as a social movement based on interdisciplinary science studies can be exposed through the concept of fandom and how their activities fall into the category of participatory culture. The forms of participation include many forms such as reflecting the knowledge which people do in Maiyah through fandom activities: developing small scale household businesses to strengthen the creative economy in the context of independence in the midst of the neoliberal economic wave, building learning communities that focus on empowering grassroots communities, etc.

All of these breakthroughs were emphasized as an effort to producing discursive strategies on the acquisition of knowledge during people immerse in Maiyah. This is the form of fandom which is constructed by Maiyah and this paper would be focussing on Mocopat Syafaat as a case study. I use also several references from digital platform to figuring out the trajectories of Maiyah in internet. In the perspective of participatory culture, it is the core of movement which articulates fandom.

\section{Maiyah and Fandom}

Multiple definitions of fandom, but most of the notions there necessarily have in common, namely linking fandom with each person to something that is considered a role model, inspiring, interesting, unique, and other cultural formations that each fan there has also a common background (Bennett, 2014: 5-20). Something chosen is usually considered unusual because it is outside the mainstream choice. The most contrasting difference between fandom and fans is marked by a tendency to totality: fans are more interested in a minor interest in a particular object that is only limited to admiration and has no special involvement with what is admired. While fandom goes beyond fans by deploying various militancy to always be involved in a relational, both emotional and practical (Coppa, 2006: 41-59).

Fandom coverage covers many kinds, but the starting point is about loving certain activities and figures. In the context of popular culture, fandom interconnects with anime, film, comics, cosplay, cartoons, music, and other communities that share a common hobby. Fandom territory, in other words, can be in the form of fashion, genre, and other well-known figures. This range is emphasized by how fandom includes a group of people who are usually referred to as communities in channeling particular pleasure.

Connections between individuals in the context of fandom become a common thread as well as showing a form of dialectical internal participation (McCardle, 2003: 9). The scope of fandom, as mentioned earlier, can help the position of Maiyah as a mass group bound by one of Cak Nun's figures symbolically and their progressive direction of movement. The congregation of Maiyah, in addition to fostering Cak Nun as the central point adopted in the learning process, also initiated a participatory movement whose orientation was still in the Maiyah circle.

In order to be aware of the cultural context of Maiyah's background, I would convey the ontological Maiyah. The term Maiyah is taken from Arabic which means togetherness (Effendy, 2009: 45-30). This naming has the purpose of the spirit of collectivity in the search for knowledge through dialogue approaches. Maiyah has another way to deconstruct "signifier" and "signified" in terms of human being, universe, and God-borrowing this term from Ferdinand de Saussurre in the book entitled Course in General Linguistics (1990) (Arnoff \& Mark, 2007: 108).

Indonesian people basically said that recitation is understood by the form which deals with religious perspective and it senses dogmatic. Different from common recitation in Indonesia, Maiyah urges people to use their mind freely. I think that is the substance of Maiyah's value 
in order to teach them alike scientists. Religion is indeed the main discourse in Maiyah, yet it has contextualized by culture, social, economics, education, and politics perspective.

In the expanse of concepts and praxis, Maiyah is a center for scientific studies guided by and through interdiscipline. Maiyah tries to deconstruct the narrowness of the community's point of view regarding seeing an object only departing from particularity. Maiyah explores the study theme from the projection of universality, even though the process of finding the answer refers to certain scientific fiedls. However, a kind of particularity is still positioned as the main element in order to embrace universality.

Such a deconstructive framework of thinking in Maiyah is dominant and dynamic, therefore Cak Nun used it as a basis of knowledge production. This understanding can be contextualized when the people in Maiyah consist of various religious, "racial", social, economic, educational, and other standard "hierarchies" that are commonly polarized in human life. Maiyah, in other words, does not distinguish personal or collective identity, because it does not refer to the definition of social class-the proletariat and the bourgeoisie - as Karl Marx predicted in Das Kapital (1867). Marx's point of view departs from the thesis of industrialization which in turn dichotomizes the human class (Brewer, 1984: 88-89). This perspective is irrelevant in Maiyah, although the historical and sociological side of the thesis can be proven empirically. Marx provided an important network for perspective, but Maiyah did not stagnate merely positioning humans as material instruments. Maiyah returns man's position as an autonomous human who has the will to be sovereign over himself, even though behind that there are preferences: socio-cultural that separates and alienates.

Explaining Maiyah in the perspective of ontology, epistemology, and axiology necessitates a theoretical framework, so we when we talk about the conception of fandom, what can be viewed and how it is systematically and comprehensively positioned are rooted there. The ontology of Maiyah bases itself on the search for knowledge, beauty, and good that is carried out continuously in the context of great values. Such an "endless" process is carried out to affirm and rediscover the sangkan (from where) and paran (to where) of humans. Such a foundation of values gives a sketch of the journey of the Maiyah people who do not only view the world as a final journey, but realize that after the world there is an afterlife. While the location of Maiyah's epistemology is described as follows.

The location of the epistemology has a verification burden that positions whether the dimension of truth that is considered true has a scientific method in order to prove the thesis it proposes. Maiyah put the epistemological domain to achieve truth as an exclusive and gradual foundation. That understanding departs from three components including truth, goodness, and beauty. The truth sought in Maiyah is not final because it cannot be separated from the relativism of who views the truth itself. In order for the truth to lie in a process, Maiyah stressed "trying together to find truth" through continuous dialectics so that when certain truths are embraced, truth on a broader scale is found. This process is never final and is conditioned so as not to stop at the truth at a certain level. Maiyah, therefore, does not pretend to "gain the truth", but "proceeds to search for the truth"- "the process" becomes Maiyah's footing so that it develops not to be tired of searching, struggling, and enjoying deal with knowledge. Maiyah avoids the "status quo" of truth that is often graded as justification. Such verification methods continue to be carried out personally and communally through behavior. This is I mention learing by doing and what we are searching for would be converted naturally by our character. The distinction among truth and justification is relatively slight actually.

Furthermore, the axiology aspect is related to the values and Maiyah focused on many things that cannot be categorized partially. Even if it is simplified so that Maiyah's orientation is 
clearly visible, there are at least three things. First, the deconstruction of values directed at "breaking down" the particular establishment which is often seen by many people as standard, stagnant, and absolute. Maiyah offers values on the results of his deconstruction as an alternative to scientific discourse. Second, the perspective reveals an object not only through the point of view, but also the resolution of the viewpoint, visibility, and side of view.

The coordinates look at something related to the subject's limitations. Maiyah conveyed such a method therefore as not to conclude something narrowly. Being entangled in conclusions on the premises that are limitative and unrepresentative will have implications for "pseudo conclusions". Maiyah, thereby, gives a sketch of plural ways of thinking out of the mainstream. Different views do not mean to diverge, but rather have special preferences why they can be different. Reasons can be argumentative depending on perspective analysis.

The theme of dialogue in Maiyah is thematic by setting specific issues, yet it does not mean closing casuistic questions from the congregation. The latter is the main point in the study of Maiyah, namely how the congregation conveyed "complaints" to be answered together - off course this submission will be responded to first by Cak Nun and other presenters on the stage.

Exploring the discussion themes in Maiyah also varied without having to stand on a certain subject. Even though it seems thin, it does not mean that the theme in Maiyah is seen as merely an instrumental, but rather transcends at the same time breaking the demarcation line that separates the arena of study discussion. This tendency means that the position of the theme depends closely on the contextual conditions, especially with the emergence of questions from broad participants. The flexibility of the thematic discussion material Maiyah provides new discourse as well as anti-thesis on public spaces with an academic nuance that is now often pinned on formal educational institutions.

Maiyah is not an institution - not even going that way-ivory towers that produce knowledge in the scientific path. Maiyah is a "alternative" socio-cultural space which can also be seen as a forum for the production, reproduction, and deconstruction of knowledge. The multidisciplinary perspective in Maiyah helped enrich the learning Islamic community in Indonesia.

The type of questions of Maiyah includes many things depending on who is asking: is it from the background of the community, businessman, students, or others. At least there are a sociological background along with questions raised by the congregants of Maiyah which will be illustrated in an illustrative way-how is the portrait of discussion in Maiyah-as follows. First, the dissemination of knowledge at the beginning of the discussion provides a general description of the particular theme as the initial perspective for dialogue to begin. This opportunity can be interpreted as a prologue to deliver discussion orientation for the next few hours. The issues raised are in response to the actual themes that occured, both on a local, national, regional and international scale.

External issues have reviewed and it enteredby multidiciplinary perspective. In such preconditions, Maiyah, in other words, provides an opportunity for contextual issues that are expected to be a slick theme for deeper comprehension. The issue does not pretend to be a representation of the "psychological question" of many people, although they have similarity. The similarity of issues felt here emphasizes how personal unease can bring plural people together in the Maiyah forum. They seemed to agree if they were in a similar question. The similarity is not entirely exact and absolute because of differences in perspective, visibility, and point of view. It can be general on the one hand and relative on the other handdepending on the context of the meaning of an issue.

Secondly, Cak Nun's invitation to discuss in the Maiyah forum promoted the process of knowledge production without the intention of essentialism and totalisation. This position makes the discussion in Maiyah try to approach verification discipline in order to formulate 
new knowledge to be more dynamic. If this side is not heeded, Maiyah's discussion will be trapped in intellectual stagnation, as have happened in other discussion forums.

Intellectual nuances that are strongly based on such dialectical tendencies direct Maiyah's discussion to go both ways, namely the theme presented and responded "actively-creatively". Borrowing the term Hegel, Maiyah tried to submit a thesis to be antithetical in order to achieve synthesis. Although the synthesis problem will become a thesis in the future because the truth of knowledge can be different in its coordinate points when contextualized with new perspectives and domains. The dialectical position was explained verbally by Cak Nun that what was delivered at a certain moment could be wrong the next day because there was a possibility of new truths that could be embraced from other struggles. At this level Maiyah moves to not intend to reach, but to approach and try to pursue an object of truth.

The truth, according to Maiyah, can be assumed to be a "mirage". Not to embrace it, but the determination to achieve it. The latter means enjoying a search process. The endless process uncovered the orientation of Maiyah, who until now has been constantly digging knowledge to enjoy the wisdom of an infinite number of sciences. Third, interconnected with the second point, Maiyah emphasizes the exploration of knowledge that does not have to be in response to the answer as soon as possible. In contrast to scientific institutional areas in other academic domains, Maiyah respects the process of illumination without finals, even questioning the reality of finalizing the search there. In such a context, Maiyah respects the process of knowledge seeking methodologies that do not stem from one version of the method alone.

The projection of Maiyah's background above-mentioned facilitates the further analysis, specifically in the context of fandom movement. The scope of fandom as a collection that has the same point of view towards certain characters, so that it moves them to carry out activities that are in line with the capital of militancy and total flow underneath, emphasizing Maiyah has certain characteristics and orientation as conceptualized fandom. What and how is the activity?

\section{Participatory Culture in Maiyah}

Henry Jenkins in his writings titled Interactive Audiences? The "Collective Intelligence" of Media Fans stated how the internet is changing and helping our lives and it has dramatically accelerated the communication between fandoms (Jenkins, 2006: 134). The speed of delivery and access to information about figures highlighted by fandoms is massive because the internet requires them without being limited by time and space. At that time and place it has also urged communities within fandom can interact without having to physically stand up. These latest technological developments that were then used by the Maiyah congregation to take part in the recitation without the need to come because simply by streaming: opening YouTube, typing the questions by keywords, downloading video footage, and only focusing on listening. The certain knowledge is presented free of charge, even if it pays only to buy an internet quota. This portrait in turn gave rise to the Maiyah congregation on YouTube.

Nowadays this reality of Maiyah is often found via the internet. They are active followers. Their appearance marks a new public space in fandom. Maiyah by YouTube marks a new chapter too: their participation tends to be free and active. This fact is explained through two characteristics as follows. First, the Maiyah congregants who are active on video-based are more likely to follow what is presented there without leaving comments or being reactively involved in the comment wall. The characteristics of this kind of congregation tend to be passive in the sense of accessing knowledge in the recitation of Maiyah only for oneself. They do not intend to spread the information they watch on other social media in the context of existential dissemination of Maiyah as well as a showcase of knowledge to fight others. 
Second, the Maiyah congregation which tends to be participatory and progressive by not only listening to the video but also leaving comments or responding to the comments of other citizens in an effort to approve or reject. This type of congregation wants a contestation of ideas which is expected to be immerse polemical and it requires the realization of a critical arena of exchange of ideas. The position is often too excessive when it has entered the distorted level like cutting videos to diversify with other videos. In addition to being closely connected with existential narratives, such tendencies are also oriented towards earning a viral position for financial gain.

Many individuals and groups claim as part of Maiyah but take advantage to gaining legitimacy by carrying out gratuitous actions - cutting the video based on popularity to be oriented viral on social media. They understand certain sentences spoken by Cak Nun on YouTube, but use them for personal-market-gain. Most of them do not use a personal account but they named it a special account by the account of Sahabat Maiyah, Pengajian Keren, and sometimes even put the name of Cak Nun directly there. The style of video distortion made by "unknown people" is easily recognized. First, cutting Cak Nun's words in the video which is actually long in duration to take words that are considered sensational and so strategic to attack others. Second, the snippet video is compiled with other that would be opposed. Usually, the source of the opposing video is taken from someone who has different perspective in order to dogma. Additionally, I regularly found Cak Nun's words that combined to governtment and they mixed it without particular context.

Third, the titles that are "clickbait" such as Inilah Jawaban Cak Nun, Viral! (Here's the Cak Nun Answer, Viral!), Pernyataan Habib Riziq Dibantah Cak Nun (Habib Riziq's statement is denied by Cak Nun), Cuman Cak Nun Yang Berani Ngomong Begini di Indonesia (Only Cak Nun who is Brave to Say This in Indonesia), and etc. The title was also made clear by the visual appearance of the video which also placed Cak Nun and other people who were about to be confronted. These three points emphasize how fandom, especially those who call themselves part of the congregation, has progressive characteristics but goes beyond limits that have actually been banned by other congregations who avoid confrontation. The participation of the Maiyah elements mentioned earlier can be traced to the reasons for doing so. If they are determined to do that, of course not solely because of their fanaticism towards Cak Nun, but also the encouragement of the internet business which has been raised dramatically.

The next question is, are there no resistance among the internal fandom groups in Maiyah in the context of addressing this? Of course, there are, but the attitudes of various worshipers in responding to the issue. What is clear is that activities such as video distortion without regard to the context of speech are prohibited by Cak Nun himself. According to him, these activities instead of bringing benefits, can actually be otherwise and it would have been longterm effected.

Efforts to resist the video distortion in the name of Cak Nun then intensified other internal fandoms in the Maiyah congregation through cyber security patterns. This was done through negotiations between the congregation and the main committee of the Maiyah called Progress. This cooperation is emphasized so that excessive oversight for sectoral interests with and through the name Cak Nun can be reduced, even though such efforts are like subverting one to one thousand.

Security in the virtual world that Maiyah is facing is how to reduce and eliminate content theft practices by an anonymous profit-oriented account. They did that by cutting the video without regard to the particular context. There are only three perspectives that are propagated by the actors: first, the Maiyah video is cut on content that is considered sexy; second, video clips with a fantastic clickbait title; and third, the briefly content of videos that have been dismantled are distributed so that many citizens visit their accounts. Those was done in the 
context of collecting capital through illegal channels. What Maiyah questioned in order to protect security is how to maintain copyright over the videos that are owned but they claimed by other parties without the owner's permission. Such a problem is even more complicated when the Maiyah has reported all forms of content theft to YouTube, but this has not diminished the existence of thieves. In fact, their existence is like a virus: one fallen thousands blossoming.

The conflict that occurred between the internal members of the Maiyah congregation, especially described above, explored how the Maiyah congregation in the perspective of fandom was impossible apart from internal friction. If the dispute is resolved it might not fully reach consensus because the conflicting party is in a relational flexibility between internal fandoms. Moreover, Maiyah here has a cultural tendency that is so dynamic in terms of the communication takes place.

Maiyah as an arena that is inseparable from the conflict of interests, especially the people that separeted as explained earlier, uncovered how its position in the concept of fandom runs dynamically and is full of negotiations to reach agreement - a kind of resolution to resolve conflicts in order to "being together" within fandom. All of this is linked from and through the Cak Nun symbolically as the central point of how the fandom is practiced. Thus, in this position, fandoms within Maiyah shapes a pattern of fandom goes beyond fans by deploying various militancy to always be involved in a relational, both emotional and practical.

\section{Conclusion}

Maiyah can be exposed in a fandom by participatory culture perspective because apart from being a study forum that focuses the search for interdisciplinary and contextual knowledge through the spirit of collectivity, it is also linked by the symbolism of Cak Nun as a figure, reference, and main core for thematic studies. The position then formed the militancy of the Maiyah toward Cak Nun which at a certain level penetrated virtual boundary so as to generate unconditional new patterns of movement in the internet. They also participated in the practice of Maiyah and at the same time enriched knowledge production during discussion as a form of fandom progression. Participation that was raised in the context of fandom in the Maiyah forum was contestative and often led to friction, but it was also quickly dealt with through negotiations between the two rival factions. Thus, Maiyah as a fandom emphasizes a form of dialogical cultural participation, even though internal conflicts there are often unavoidable but in turn are handled well.

\section{Acknowledgement}

I am deeply indebted to my academic supervisor, Dr. Budiawan in Media and Cultural Studies, Gadjah Mada University, for warm support, inspiration, and thoughful guidance. I would like also to thank Cak Nun, Helmi Mustofa, and Ahmad Karim for their technical support during the research. This research was funded and supported by Indonesia Endowment Fund for Education (LPDP). In this great chance, I want to say thanks to LPDP for all the help. I hope that it would make a huge impact on my academic's career.

\section{References}

Aronoff, M., \& Rees-Miller, J. (2017). The Handbook of Linguistics. Hoboken, NJ: John Wiley \& Sons. p. 108.

Bennett, L. (2014). Tracing Textual Poachers: Reflections on the Development of Fan Studies and Digital Fandom. The Journal of Fandom Studies. pp. 5-20. 
Brewer, A. (1984). A Guide to Marx's Capital. Melbourne: Cambridge U.P. pp. 88-89.

Coppa, F. (2006). A Brief History of Media Fandom dalam Fan Fiction and Fan Communities in the Age of the Internet. Jefferson, North Carolina: McFarland \& Company. pp. 41-59.

Effendy, A. F. (2009). Maiyah di dalam Al-Qur'an. Malang: Misykat. pp. 45-30.

Hadi, S. (2011). Pemikiran Emha Ainun Nadjib dalam Tinjauan Filsafat Humanisme: Kontribusinya bagi Perkembangan Kehidupan Sosial. Master Thesis: Gadjah Mada University. p. 54.

Henry, J. (2006). Fans, Bloggers, and Gamers. New York: NYU Press. p. 134.

J.G. dan Tatsuoka M.M. (1968). Scientific Thought. Boston. pp. 67-68.

McCardle, M. (2003). Fan Fiction, Fandom, and Fanfare: What's All the Fuss? Boston: Trustees of Boston University. p. 9.

Peacock, J.L. (1978). Purifying the Faith: The Muhammadijah Movement in Indonesian Islam. Cummings Press.

Robert, W. (1993). "Islam, State, and Civil Society: ICMI and the Struggle for the Indonesian Middle Class" in Southeast Asia Program Publications at Cornell University. Indonesia, (56), 1-35. http//www.jstor.org/stable/3351197

Rozi, M. (2005). Negeri Kecil di Negeri Besar: Studi tentang Upacara Ritual Komunitas Maiyah di Bantul Yogyakarta. Master Thesis: Gadjah Mada University. p. 64. 